\title{
Contents, Volume 8 (1997)
}

Atlegrim, O., Sjöberg, K. \& Ball, J. P.: Forestry effects on a boreal ground beetle community in spring: Selective logging and clear-cutting compared $19-26$

Bengtsson, B. A.: Notes on interesting scythridids in the Zoological Museum, Helsinki, Finland (Lepidoptera, Scythrididae) 89-102

Biström, O., Nilsson, A. N. \& Wewalka, G.: A systematic review of the tribes Hyphydrini Sharp and Pachydrini n. trib. (Coleoptera, Dytiscidae) $57-82$

Buhl, P. N.: Five new species of Platygastroidea from Norway (Hymenoptera) 197-204

Hirvenoja, M.: Delimitation of the pupae of the European species of the subgenus Camptochironomus (Diptera, Chironomidae)

215-218

Hirvenoja, M. \& Michailova, P.: On the karyology and morphology of Chironomus jonmartini Lindeberg (Diptera, Chironomidae) 39-55

Itämies, J. \& Tabell, J.: Variation in male genitalia of Coleophora vacciniella H.-S. (Lepidoptera, Coleophoridae) ... $145-150$

Jonsson, M., Nordlander, G. \& Jonsell, M.: Pheromones affecting flying beetles colonizing the polypores Fomes fomentarius and Fomitopsis pinicola .............. 161-165

Kaila, L.: Two new Elachista species (Lepidoptera, Elachistidae) from the Polar Urals region, Russia ....... 219-223

Kononenko, V. S. \& Mikkola, K.: Apamea yunnana sp. n. (Lepidoptera, Noctuidae) from northem Yunnan, China 83-85

Koponen, S., Rinne, V. \& Clayhills, T.: Arthropods on oak branches in SW Finland, collected by a new trap type ... 177-183

Lafer, G. Sh., Nilsson, A. N. \& Kholin, S. K.: Additional records and new synonyms of Cicindelidae and Carabidae (Coleoptera) from the Island of Sakhalin in the Russian Far East 13-17

Mikkola, K.: Population trends of Finnish Lepidoptera during 1961-1996 $121-143$

Nummelin, M.: Wing dimorphism of the water strider Limnogonus franciscanus (Stål) (Heteroptera: Gerridae) in a seasonal tropical climate ................................. 167-170

Nummelin, M., Lodenius, M. \& Tulisalo, E.: Water striders (Heteroptera, Gerridae) as bioindicators of heavy metal pollution 185-191

Pekkarinen, A.: Parasitism of Stylops (Strepsiptera, Stylopidae) in poly- and oligolectic Andrena hosts (Hymenoptera, Apoidea) 109-111

Pekkarinen, A.: Oligolectic bee species in Northern Europe (Hymenoptera, Apoidea) .............................. 205-214

Price, P. W., Roininen, H. \& Tahvanainen, J.: Willow tree shoot module length and the attack and survival pattern of a shoot-galling sawfly, Euura atra (Hymenoptera: Ten(hredinidae) 113-119

Valkama, H., Martikainen, P. \& Räty, M.: First record of North American ambrosia beetle Gnathotrichus materiarius (Fitch) (Coleoptera, Scolytidae) in Finland - a new potential forest pest? 193-195
Valkama, H., Räty, M. \& Niemelä, P.: Catches of Ips duplicatus and other non-target Coleoptera by Ips typographus pheromone trapping ....................................... 153-159

Vikberg, V.\& Nuorteva, M.: On the rearing of Nesoselandria morio (Fabricius) and Birka cinereipes (Klug) (Hymenoptera, Tenthredinidae), with descriptions of their larvae 27-38

Wikström, B., Kerppola, S. \& Šulcs, I.: The redescription of Coleophora carelica Hackman (Lepidoptera, Coleophoridae) 9-12

Wülker, W. F.: Chironomus esai n. sp. (Diptera: Chironomidae) in lakes and reservoirs of central Fennnoscandia .... $171-176$

\section{Brief report}

Bruun, H. H. \& Itämies, J.: The larval mine of Stigmella lappovimella (Svensson, 1976) on Salix lapponum (L.) (Lepidoptera, Nepticulidae) .......................... 103-107

Humala, A. E.: New findings of Parnassius mnemosyne Linnaeus (Lepidoptera, Papilionidae) in Russian Karelia

\section{4}

Itämies, J. \& Várkonyi, G.: Notes on the biology of Entephria polata (Lepidoptera, Geometridae) .................... 87-88

Koponen, S.: Triaeris stenaspis Simon (Araneae, Oonopidae) found in the Botanical Garden of the University of Turku, Finland \section{... 7}

Silfverberg, H.: A new replacement name in Curculionidae (Coleoptera) ….................................................... 160

Várkonyi, G., Itämies, J. \& Pyömilä, A.: Trogus lapidator (Fabricius) ssp. panzeri Carlson (Hymenoptera, Ichneumonidae) in Finland: new rearing records and comments on its distribution $5-6$

Short reports (titles modified)

Finneman, J.: New provincial record of the Lepidoptera Hellinsia distincta (Herrich-Schäffer) (Pterophoridae) .. $2-3$

Haarto, A.: Sciopus contristans (Wiedemann) (Dolichopodidae), Platycheirus amplus Curran (Syrphidae), P. nielseni Vockeroth (Syrphidae), P. occultus Goeldlin, Maibach \& Speight (Syrphidae), Epistrophella euchroma (Kowartz) (Syrphidae), Epistrophe cryptica Dozckal \& Schmid (Syrphidae), Eupeodes latilunulatus (Collin) (Syrphidae), E. borealis (Dusek \& Laska) (Syrphidae) and Lydella ripae Brischke (Tachinidae), nine species of Diptera new to Finland

Haarto, A.: New provincial records of the Diptera Eupeodes abiscoensis (Dusek \& Laska) (Syrphidae), Sphaerophoria bankowskae Goeldlin (Syrphidae), Protophormia terraenovae (Robineau-Desvoidy) (Calliphoridae) and Helicophagella melanura (Meigen) (Sarcophagidae) ....... 2-3 Kanervo, J.: Amphigerontia intermedia (Tetens) (Psocidae), 
a species of Psocoptera new to Finland

Nurminen, J.: Faunistic rarities, Lepidoptera Schinia scutosa (Denis \& Schiffermüller) (Noctuidae) and Cosmia pyralina (Denis \& Schiffermüller) (Noctuidae) .... 3

Rantanen, A.: Faunistic rarities, Lepidoptera Malacosoma neustria (Linnaeus) (Lasiocampidae) and Xanthia gilvago (Denis \& Schiffermüller) (Noctuidae) 3

\section{Reviews}

Maitland Emmet, A. (ed.) 1996: The moths and butterflies of Great Britain and Ireland. Volume 3. YponomeutidaeElachistidae (Juhani Itämies) $151-152$

Nilsson, A. 1996: Aquatic insects of North Europe. A taxonomic handbook (Juhani Itämies) 4

Puplesis, R. 1994: The Nepticulidae of Eastern Europe and Asia: western, central and eastem parts (Kauri Mikkola)
Remaudiére, G. \& Remaudiére, M. 1997; Catalogue des Aphididae du Monde - Catalogue of the World's Aphididae. Homoptera Aphidoidea (O. Heikinheimo) ...... 108

Announcements

6th European Congress of Entomology České Budějovice, Czech Republic August 21-27, 1998

XIth European Congress of Lepidopterology: Malle, Belgium, 22-26 March 1998

86

XXIV Nordic Congress of Entomology: Tartu, Estonia, August 8 to 11,1997 18

INDEX to genera and species, Volume 8 (1997) . 225-236 CONTENTS, Volume 8 (1997) .......................... 237-238 